\title{
Impact of Information Technology on Profitability of Airlines Industry: A Case Study of Royal Jordanian Airlines
}

\author{
Omar A. A Jawabreh ${ }^{1}$, Mahmoud Allahham ${ }^{2}$, Ashraf Alrjoub ${ }^{3} \&$ Muhannad Ahmad $^{3}$ \\ ${ }^{1}$ Department of Tourism and Hotels Sciences, Al-Balqa Applied University, Salt, Jordan \\ ${ }^{2}$ Faculty of Administrative and Finance Science, Medile East University, Amman, Jordan \\ ${ }^{3}$ Faculty of Administrative and Finance Science, Irbid National University, Irbid, Jordan \\ Correspondence: Omar A. A Jawabreh, Department of Tourism and Hotels Sciences, Al-Balqa Applied \\ University, Salt, Jordan. Tel: 962-777-294-671. E-mail: ojawabreh2000@yahoo.com
}

Received: May 22, 2012 Accepted: July 16, 2012 Online Published: September 16, 2012

doi:10.5539/ijbm.v7n18p149 URL: http://dx.doi.org/10.5539/ijbm.v7n18p149

\begin{abstract}
This paper explores Impact of information technology on profitability of airlines industry "a case study of Royal Jordanian Airlines, The data collected from the financial statement of Royal Jordanian Airlines is analyzed by using financial and statistical tools. The tools and techniques issued in this study are discussed here. It is very difficult to cover several of aspects of financial management of Royal Jordanian Airlines; hence, focus has been given to study the profitability, capital structure \& working capital management.

The financial measures of performance are well adequate to monitor returns on IT. This is important as IT specialists always require special measures for IT performance, the current results show that IT do affect the aggregate financial performance measures. Which make them suitable for IT investments assessments?
\end{abstract}

Keywords: impact of information technology, profitability, royal Jordanian airlines, gross profit ratio, net profit ratio

\section{Introduction}

Airlines' immediate focus is on cost reductions in driving to operations that are more efficient. However many airlines are turning to customer relationship management (CRM) as a tool for managing customer relationships. Unfortunately, in many cases, they have failed to recognize CRM as a holistic strategy, instead viewing it as synonymous with their frequent flyer programs.

As airlines struggle to gain market, share and sustain profitability in today's fiercely competitive and economically demanding environment, they must develop new ways to manage their customer relationships to optimize customer loyalty and revenues. What tactics should airlines use to acquire, develop and retain customers with greater precision and improved results?

Over the last years, individuals and organizations in Jordan and all over the world have invested significantly in information technologies and systems. It is widely believed that strategic information technology (IT) investments will enable firms to cut costs and working effectively. However, there are concerns about the choice of these technologies and their deployment and hence the organization's ability to successfully achieve appropriate returns from these technologies.

Travel products and services possess many characteristics needed to function in the electronic environment. The ease of description and commodity-like nature of many travel products (such as airline seats or hotel rooms) suggests that the travel industry exhibits the product attributes that are favorable for electronic commerce.

U.S. airlines currently spend $\$ 6.4$ billion annually on travel agent commissions, although this total amount is now declining as carriers significantly reduce their payments to agencies.

With online booking and E-tickets, the last physical objects needed to reserve and undertake travel disappear. Electronic ticketing therefore serves as an enabler for automated delivery of travel products. Also, any direct communication between travelers and travel suppliers such as airlines and hotels supports the collection of valuable consumer information by the supplier, which suppliers such as airlines do not wish to share with third parties. Knowledge of consumer behavior, including buying profiles and purchases of related products (such as 
rental cars), is critical information that serves as the basis for developing marketing strategies; the information collected by airlines on their frequent flyers is an example.

\section{Literature Review}

Albert H. Segars Varun Grover (1995). As noted by several observers, information technology (IT) has rapidly evolved from "part of the organizational overhead" into a strategic resource capable of changing patterns of competition within industries [8, p. 275]. However, while this evolution has become part of the fabric for literature exploring the strategic impact of IT, very few studies have been undertaken to determine the specific influence(s) of technology-based competition on industry structure. The development of analytical frames for capturing aspects of industry behavior provides a potentially powerful tool for evaluating the influence strategic IT initiatives may have on current bases of competition. Drawing from the theoretical disciplines of industrial economics and strategic management, this study develops a framework for analyzing longitudinal changes in industry structure. Working within this frame, the study then analyzes the nature and change of structure in three industries during and after the introduction of strategic information technology. The findings suggest that in each of these industries structural characteristics were dramatically altered subsequent to the introduction of competitive-based IT. In two of the industries (airlines and industrial chemicals), early adopters broke away from other industry participants, in effect, forming unique bases of competition. In the remaining industry (drug wholesalers), previously distinct bases of competition consolidated, resulting in a more competitive industry structure than that which existed prior to the technological innovation.

A study by Gomes (2009) under the title "Internet Banking" the study aimed to identify the banking services through internet in India and the security risks that may face these services.

A study by Dr. Tauseef, Ahmad (2011) under the title: Impact of Information Technology on Banking Accounting System "A Case Study of State Bank of India (Rajasthan)". The impact of information technology on work life has been one of the most talked about issues over the recent years.

(Laudon, K. C., Laudon, J. P., 1998. Management Information Systems) Technology can improve the internal and external communication of organizations. This is fundamental in the integration of how an organization interprets what is happening outside with the notion of "how things are done here", Its improve interconnections in the value chain, significantly reducing the coordination costs among activities and risks inherent to transactions.

J.G.M. van der Heijden (1996). Leisure travelers are interested in a convenient way to access information such as airline schedules and fares, and obtain personalized advice or share past experiences.

Dimitrios Buhalis (2004) Information Communication Technologies (ICTs) have revolutionized the entire business world. The airline industry in particular has fostered a dependency on technology for their operational and strategic management. Airlines were early adopters of ICTs and have a long history of technological innovation, in comparison to many other travel and tourism businesses. This paper discusses comprehensive research, including exploratory research with airline executives, using qualitative methods to examine the use of ICTs in the contemporary airline industry and to discuss recent developments in the industry. The work demonstrated that the airline industry was using the Internet to improve its distribution strategy and reduce costs; it also used Intranets and internal systems to develop tactical and strategic management. In addition, Extranets were being gradually used for communicating with partners and to support business-to-business (B2B) relationships. The effort demonstrated that ICTs will be critical for the strategic and operational management of airlines and will directly affect the future competitiveness of airlines.

Dussauge, P., Hart, S., and Ramanantsoa B., 1994 (Strategic Technology Management), technology is a factor that affects many aspects of the firm strategy. Porter points out that its offer new innovative ways to compete through the reduction of costs and the differentiation of products.

Dimitrios Buhalis (1998) (ITs) prevail in all functions of strategic and operational management. As information is the lifeblood of tourism, ITs provide both opportunities and challenges for the industry. Despite the uncertainty experienced in the development of ITs in tourism, the 'only constant will be change'. Increasingly, organizations and destinations, which need to compete, will be forced to compute. Unless the current tourism industry improves its competitiveness, by utilizing the emerging ITs and innovative management methods, there is a danger for exogenous players to enter the marketplace, jeopardizing the position of the existing ones. Only creative and innovative suppliers will be able to survive the competition in the new millennium. This paper provides a framework for the utilization of technology in tourism by adopting a strategic perspective. A continuous business process re-engineering is proposed in order to ensure that a wide range of prerequisites such 
as vision, rational organization, commitment and training are in place, so they can enable destinations and principals to capitalize on the unprecedented opportunities emerging through ITs.

\section{Research Objectives}

The main objective of this study is to examine the relationship between IT and financial performance by estimating the contribution of IT investment to airlines performance measured by financial ratios, in the same year of investment, the second year (one-year lag effect), or the third year of the investment (two-year lag effect).

The financial analysis is the process of determining the significant characteristics of the company. The proposed study is an attempt to obtain a true insight into the financial position of Royal Jordanian Airlines. It seeks to study the changes that have taken place therein over a given period of time and to judge profitability and financial strength and changes therein with the help of comparison of individual company's ratios with standard ratios.

Another important objective is to examine whether the inclusion of factors that measure organizations' ability to implement successful information technology investments will moderate the relationship under study to measure the true impacts of IT.

\section{Importance of the Study}

The importance of this study streams form the following points:

Managers have begun to insist that much more attention be paid to the economic aspects of information systems than ever before and this has lead to an increasing demand for a comprehensive and reliable IT performance evaluation.

To the best of the researcher knowledge, this work is the first attempt to investigate information technology and financial performance relationship quantitatively in the financial sector of Royal Jordanian Airlines.

This study is one of few other studies executed outside Jordan, specifically in the developing countries, to be added to the previous studies.

\section{Analytical Techniques}

The data collected from the financial statement of Royal Jordanian Airlines are analyzed by using financial and statistical tools. The tools and techniques issued in this study are discussed here. It is very difficult to cover several of aspects of financial management of Royal Jordanian Airlines; hence, focus has been given to study the profitability, capital structure \& working capital management.

\subsection{Hypotheses}

Based on the previous research questions, the following null hypotheses have been formulated:

Ho: There is no significant relationship between accumulated information technology (IT) capital and the Royal Jordanian Airlines' financial performance.

Ho: There is no significant relationship between annual IT investments and the Royal Jordanian Airlines' financial performance.

Ho: There is no significant relationship between previous years accumulated IT capital and the Royal Jordanian Airlines' financial performance.

Ho: Capital structure and profitability are interrelated

Ho: An adequate amount of working capital increased the efficiency of the business

Ho: There is no significant difference in the observed and expected value of the profits

\subsection{Analysis of Profitability of Royal Jordanian Airlines through Ratio Analysis}

The objective of profitability relates to a company's ability to earn a satisfactory profit so that the investors and shareholders will continue to provide capital to it. A company's profitability is linked to its liquidity because earnings ultimately produce cash flow. For these reasons ratios are important to both investors and shareholders.

When calculating profitability ratios we always use Profit on ordinary activities before taxation because there might be unusual variations in the tax charge from year to year which would not affect the underlying profitability of the company's operation.

Another important profit figure used should be the Profit before interest and tax (operating profit) which represents the profit generated by the entity through its normal business operations. 
A low gross project margin may reflect higher cost of goods sold due to firm's inability to purchase raw materials at favorable terms, inefficient utilization of plant and machinery, or over investment in plant and machinery, resulting into higher cost of production. The ratio will also be low due to a fall in prices in the market, or marked reduction in selling price by the firm in an attempt to obtain large sales volume, the cost of goods sold remaining unchanged.

\subsubsection{Interpretation}

Table 1. Gross profit ratio of royal Jordanian airlines

\begin{tabular}{cccc}
\hline Year & Sales & Gross Profit & Gross Profit (\%) \\
\hline 2001 & 217217 & -4535 & -2.09 \\
2002 & 238879 & 11573 & 4.84 \\
2003 & 270727 & 8017 & 2.96 \\
2004 & 362840 & 32916 & 9.07 \\
2005 & 413166 & 42153 & 10.20 \\
2006 & 447049 & 12937 & 2.89 \\
2007 & 542584 & 32992 & 6.08 \\
2008 & 702691 & 30122 & 4.29 \\
2009 & 598260 & 52115 & 8.71 \\
2010 & 515776 & 65449 & 12.69 \\
Average & 430918.9 & 9362.9 & 5.96 \\
Standard deviation & 153281.5 & 12969.3 & 4.096218 \\
Coefficient of variation & 0.35570 & 1.38517 & 3.0868 \\
\hline
\end{tabular}

Source: Annual reports of royal Jordanian airlines from 2001-2010

Table 1 shows that the Gross Profit Ratio in Royal Jordanian Airlines registered a fluctuating trend throughout the period under study. For the year 2001, the gross profit ratio was -2.09 percent which increased to 4.84 percent in 2002 but decreased to 2.96 percent in 2003 then it increased to 9.07 percent in 2004 again increases in 2005 to be 10.20 percent, came down to 2.89 percent in 2006 . After that, it increased to 6.08 percent in 2007, came down to 4.29 in 2008 , increased further to 8.71 percent in 2009 and finally, decreased up to 12.96 percent in the final year 2010 of the period under study.

Net profit is obtained when operating expenses, interest and taxes are subtracted from gross profit. In the present research work, the net profit ratio of the Royal Jordanian Airlines under study has been calculated by using the following formula:

$$
\text { Net Profit Ratio }=\frac{\text { Net Profit after Tax }}{\text { Net Sales }} \times 100
$$

Table 2. Net profit ratio in royal Jordanian airlines (Amount in thousands JD)

\begin{tabular}{cccc}
\hline Year & Sales & NPAT & Net Profit (\%) \\
\hline 2001 & 217217 & -12116 & -5.58 \\
2002 & 238879 & -3043 & -1.27 \\
2003 & 270727 & -9753 & -3.60 \\
2004 & 362840 & 15327 & 4.22 \\
2005 & 413166 & 20516 & 4.97 \\
2006 & 447049 & 6135 & 1.37 \\
2007 & 542584 & 20363 & 3.75 \\
2008 & 702691 & 14038 & 2.00 \\
2009 & 598260 & 28614 & 4.78 \\
2010 & 515776 & 13548 & 2.63 \\
Av & 430918.9 & 9362.9 & 1.327 \\
S.D & 153281.5 & 12969.3 & 3.468631 \\
C.V & 0.35570 & 1.38517 & 2.61388 \\
\hline
\end{tabular}

Source: Annual reports of royal Jordanian Airlines, from 2001-2010 
Table 2 shows that the Net Profit Ratio for Royal Jordanian Airlines registered fluctuating trend during the period under study. The ratio fluctuated within the range of -5.58 percent (lowest) to 4.97 percent (highest). The net profit ratio was (-5.58) percent in the year 2001 which increased to -1.27 percent in 2002, decreased to -3.60 in 2003, and increased to 4.22 percent in 2004, in 2005 it's increased to 4.97 (the highest), Then, it came down in 2006 to 1.37 and 3.75 percent in 2007 and again came down to 2.00 percent in 2008 , then increased to 4.78 in 2009. Finally, in the year 2010 in came down slightly and reached 2.63 percent. The reasons behind the net profit up and down are increasing of the fuel prices, services are not prepare as per the international requirements, increasing of taxes, maintenance are very costly and there are competitions of airlines.

\subsubsection{Statistical Analysis}

Correction Factor $($ C.F. $)=\left(\mathrm{T}^{2}\right) / \mathrm{N} ; \mathrm{N}=10 ; \mathrm{N}=30 ; \mathrm{T}=\Sigma \mathrm{X}_{1}+\Sigma \mathrm{X}_{2}+\Sigma \mathrm{X}_{3}$

Where $\mathrm{T}=430918+9362.90+1.327 ;$ AVERAGE $=146761.042$

Total Sum of Squares $(\mathrm{TSS})=\Sigma \mathrm{X}_{1}{ }^{2}+\Sigma \mathrm{X}_{2}{ }^{2}+\Sigma \mathrm{X}_{3}{ }^{2}+\Sigma \mathrm{X}_{4}{ }^{2}-\left(\mathrm{T}^{2}\right) / \mathrm{N}=146761.042$

Sum of Squares between the Companies ( $\mathrm{SSC})=\left(\Sigma \mathrm{X}_{1}\right)^{2} / \mathrm{N}_{1}+\left(\Sigma \mathrm{X}_{2}\right)^{2} / \mathrm{N}_{2}+\left(\Sigma \mathrm{X}_{3}\right)^{2} / \mathrm{N}_{3}+\left(\Sigma \mathrm{X}_{4}\right)^{2} / \mathrm{N}_{4}-\left(\mathrm{T}^{2}\right) / \mathrm{N}$

$=1211623516350.816$

$\mathrm{SSR}=\mathrm{TSS}-\mathrm{SSC}=146761.042-1211623516350.816=236634319750.114$

Table 3. ANOVA, Sum of squares, mean and $\mathrm{F}$ test

\begin{tabular}{lcccc}
\hline Source of Variation & Sum of Squares & d.f Squares & Mean & F \\
\hline SSC & 12116235156350.816 & 2 & 605811756 & 96.1232 \\
SSR & 236634319750114 & 27 & 87642340 & 64.819 \\
SST & 1448257836100.93 & 29 & & \\
\hline
\end{tabular}

\subsubsection{F-test for NP to Sales Ratio}

Table 3 Since the calculated value of F-ratio (96.1232) is more than the critical value of F (2.51061) at 5\% level of significance, hence the null hypothesis is rejected and therefore it is concluded that the Net Profit of Royal Jordanian Airlines ratio does not differ significantly as the Net Profit is .comparative to the sales is significant and is increasing trend.

\subsubsection{Operating Profit Ratio}

The operating profit refers to the pure operating profit of a firm i.e. the profit generated by the operation of the business concern and hence, it is calculated before considering any financial charge (such as inter payment), non-operating income/loss and tax liability etc. The operating profit is also termed as Earnings before Interest and Taxes (EBIT). The operating profit ratio may be calculated as follows:

$$
\text { Operating profit Ratio }=\frac{\text { Earning Before Interest and Taxes }}{\text { Net Sales }} \times 100
$$

Table 4. Operating profit ratio of royal Jordanian airlines

\begin{tabular}{cccc}
\hline Year & Sales & Operating Profit & Operating Profit (\%) \\
\hline 2001 & 217217 & -13979 & -6.44 \\
2002 & 238879 & -946 & -0.40 \\
2003 & 270727 & -5376 & -1.99 \\
2004 & 362840 & 15397 & 4.24 \\
2005 & 413166 & 22778 & 5.51 \\
2006 & 447049 & -6729 & -1.51 \\
2007 & 542584 & 12412 & 2.29 \\
2008 & 702691 & 7271 & 1.03 \\
2009 & 598260 & 31875 & 5.33 \\
2010 & 515776 & 12512 & 2.43 \\
Average & 4309189 & 7521.5 & 1.049 \\
Standard deviation & 153281.5 & 13565.23 & 3.5472 \\
Coefficient of variation & 0.3557 & 1.8035 & 3.3815 \\
\hline
\end{tabular}

Source: Annual reports of royal Jordanian airlines from 2001-2010 
As given in table 4 for Royal Jordanian Airlines, the Expenses Ratio showed a fluctuating trend during 2001 to 2010. Starting from -6.44 percent in 2001 , it increased to 5.51 percent in $2005,-0.40$ percent in 2002 and reached -1.99 percent in 2003. Then, it increased to 4.24 percent in 2004, 5.51 percent in 2005 and came down to -1.51 percent in 2006 to 2.29 percent in 2007 and came down in 2008 to be 1.03 and increased in 2009 to 5.33. Finally, it decreased up to 2.43 percent in 2010.

The Operating Profit Ratio shows the percentage of pure profit earned on every 1 dinar of sales made. The Operating Profit Ratio will be less than the Gross Profit Ratio as the indirect expenses such as general and administrative expenses, selling expenses and depreciation charges etc. are deducted from the gross profit to arrive at the operating profits. Thus, the Operating Profit Ratio measures the efficiency with which the firm not only manufactures/ purchases the goods but also sells the goods. The Operating Profit Ratio in conjunction with the Gross Profit Ratio can depict whether the changes in profitability of the firm are caused by change in manufacturing efficiency or administrative efficiency. It can help identify the corrective measures to improve the profitability.

To have an idea of the variation in Operating Ratio, Expenses Ratio has been calculated in the present study, The Operating Ratio has been decomposed with (a) cost of services provides , and (b) other operating expenses.

Table 5. Operating expenses ratio of royal Jordanian airlines (Amount in thousands JD)

\begin{tabular}{cccc}
\hline Year & Operating Exp. & Sales & Operating Ratio \\
\hline 2001 & 9444 & 217217 & 4.3 \\
2002 & 12519 & 238879 & 5.2 \\
2003 & 13393 & 270727 & 4.9 \\
2004 & 17519 & 362840 & 4.8 \\
2005 & 19375 & 413166 & 4.7 \\
2006 & 19666 & 447049 & 4.4 \\
2007 & 20580 & 542584 & 3.8 \\
2008 & 22851 & 702691 & 3.3 \\
2009 & 20240 & 598260 & 3.4 \\
2010 & 52937 & 515776 & 10.3 \\
Average & 20852.4 & 430918.9 & 4.91 \\
Standard deviation & 11418.44 & 153281.5 & 1.895495 \\
Coefficient of variation & 0.54738 & 0.3557 & 0.3860 \\
\hline
\end{tabular}

Source: Annual Reports of Royal Jordanian Airlines from 2001 - 2010

For Royal Jordanian Airlines, the Operating Profit Ratio showed a fluctuating trend as can be seen from table 5; the ratio fluctuated within the range of 3.3 percent (lowest) in 2008 to 10.3 percent (highest) in 2010. The operating profit ratio was 4.3 percent in the year 2001 which increased to 5.2 percent in $2002,4.9$ percent in 2003 ,came down to 4.8 in 2004 and in 2005 to 4.7 , it came down continuously as 4.4 in 2006. In 2007 it came down also to become 3.8 and reached 3.3 (the lowest) in 2008. With slightly increase in 2009 to 3.4 . Then, it increased to 10.3 (the highest) percent in 2010.

The Expenses Ratio provides a yardstick of operating efficiency. The operating Expenses Ratio is affected by a number of factors, such as external uncontrollable factors, internal factors, employees and managerial efficiency (or inefficiency), etc which should be studied cautiously because these are very difficult to analyze. Further, it should be noted that the Expenses Ratio cannot be used as a test of financial condition in the case of those firms where non-operating revenue and expenses form a substantial part of the total income.

\subsubsection{Statistical Analysis}

Correction Factor (C.F.) $=\left(\mathrm{T}^{2}\right) / \mathrm{N} ; \mathrm{N}=10 ; \mathrm{N}=30$;

AVERGE $=150592.070$ 
So, Total Sum of Squares (TSS) $=\Sigma \mathrm{X}_{1}{ }^{2}+\Sigma \mathrm{X}_{2}^{2}+\Sigma \mathrm{X}_{3}{ }^{2}+\Sigma \mathrm{X}_{4}{ }^{2}-\left(\mathrm{T}^{2}\right) / \mathrm{N}=12036.88+161572.92+1.998$

$=141717616257.463$

Sum of Squares between the Companies $(\mathrm{SSC})=\left(\Sigma \mathrm{X}_{1}\right)^{2} / \mathrm{N}_{1}+\left(\Sigma \mathrm{X}_{2}\right)^{2} / \mathrm{N}_{2}+\left(\Sigma \mathrm{X}_{3}\right)^{2} / \mathrm{N}_{3}+\left(\Sigma \mathrm{X}_{4}\right)^{2} / \mathrm{N}_{4}-\left(\mathrm{T}^{2}\right) / \mathrm{N}$

$=11809200634.234$

$\mathrm{SSR}=\mathrm{TSS}-\mathrm{SSC}=11809200634.234-141717616257.463=236256099193.229$

Table 6. ANOVA, sum of squares, mean and $\mathrm{F}$ test

\begin{tabular}{ccccc}
\hline Source of Variation & Sum of Squares & d.f Squares & Mean & F \\
\hline SSC & 11809200634.234 & 2 & 590460031732.117 & 67.479 \\
SSR & 236256099193.229 & 27 & 149815363.471 & \\
SST & 1417176162657.463 & 29 & & \\
\hline
\end{tabular}

\subsubsection{F-test for Inventory to Current Assets Ratio}

Table 6 Since the calculated value of F-ratio (67.479) is more than the critical value of F (2.51061) at 5\% level of significance, hence the null hypothesis is rejected and it can be concluded that the operating expenses of Royal Jordanian Airlines ratio differ significantly as the operating ratio is comparative to sales and operating expenses are according to sales is within the controlling limit.

\subsubsection{Profitability Based on Investments/Assets}

Financial analysis can also be made by employing another set of financial ratio to find out how efficiently a business firm is using its assets because the profitability of a business concern can also be analyzed with reference to the assets employed to earn a return. Generally, the more the assets employed, the greater should be the profits and vice-a-versa. Profitability based on sales as calculated in earlier section devoted the profit margin contributed on diner of sales. The profitability based on investments/assets is used to analyze the profits earned per diner of investments made in the business. There are different concepts of assets employed or investments made in the business such as total assets, tangible assets, net assets, fixed assets, capital employed etc. Accordingly, there can be different profitability ratios based on assets/investments of the business but in the present study, following ratios have been calculated:

Table 7. Return on investment trend in royal Jordanian airlines

\begin{tabular}{cccc}
\hline Year & NPAT+I & Total Assets (Net) & Return on Total Asset (\%) \\
\hline 2001 & -2407 & 152967 & -1.6 \\
2002 & 5250 & 146030 & 3.6 \\
2003 & -3018 & 13614 & -2.2 \\
2004 & 20578 & 139225 & 14.8 \\
2005 & 24980 & 143762 & 17.4 \\
2006 & 11171 & 125484 & 8.9 \\
2007 & 24471 & 175799 & 13.9 \\
2008 & 18169 & 227558 & 8.0 \\
2009 & 31215 & 219776 & 14.2 \\
2010 & 15197 & 198226 & 7.7 \\
Average & 14560.6 & 154244.1 & 8.47 \\
Standard deviation & 11085.43 & 57512.52 & 6.49693 \\
Coefficient of variation & 0.76133 & 0.3728 & 0.7670 \\
\hline
\end{tabular}

Source: Annual reports of royal Jordanian airlines from $2001-2010$ 
As can be seen from Table7, for Royal Jordanian Airlines, the return on total assets trend Ratio showed a fluctuating trend during 2001 to 2010. Starting from -2.2 percent in 2003, it decreased to 17.4 percent in 2005 .

It reached to 7 percent in 2001 . Then, it decreased to -2.2 percent in 2003 and increased sharply to 14.8 percent in 2004. Then, it increased sharply to 17.4 percent in 2005 but decreased equally to 8.9 percent in 2007 .then increased to 13.9 percent in 2007 , and came down to 8.0 percent in 2008. Finally, it increased up to 14.2 percent in 2009 and came down to 7.7 percent in 2010.

\subsubsection{Statistical Analysis}

Total no $=10$

$$
S_{n-1}^{2}=\frac{1}{n-1} \sum_{i=1}^{n}\left(X_{i}-\bar{X}\right)^{2}=\frac{1}{n-1}\left(\sum_{i=1}^{n} X_{i}^{2}-n \bar{X}^{2}\right)=11685.066
$$

Population SD $=11085.42697$

Variance $=\sigma^{2}=136540767.8222$

Variance Population $=\sigma^{2}=122886691.04$

Total Assets Net

$\mathrm{N}=30 ; \mathrm{T}=\Sigma \mathrm{X}_{1}^{2}+\Sigma \mathrm{X}_{2}^{2}+\Sigma \mathrm{X}_{3}^{2}+\Sigma \mathrm{X}_{4}^{2} ; \Sigma \mathrm{X}=145606, \Sigma \mathrm{X}=1542441, \Sigma \mathrm{X}=84.7 ; \mathrm{MEAN}=14560.6$

$\mathrm{TSS}=\left(\Sigma \mathrm{X}_{1}\right)^{2} / \mathrm{N}_{1}+\left(\Sigma \mathrm{X}_{2}\right)^{2} / \mathrm{N}_{2}+\left(\Sigma \mathrm{X}_{3}\right)^{2} / \mathrm{N}_{3}+\left(\Sigma \mathrm{X}_{4}\right)^{2} / \mathrm{N}_{4}-\left(\mathrm{T}^{2}\right) / \mathrm{N}=3348977634+270989321+139.51$

Variance: $\mathrm{S} . \mathrm{D}=11685.0 \quad 60623.51 \quad 6.8484$

$$
\text { C.V }=3695.14 \quad 19170.84 \quad 2.1651
$$

Table 8. ANOVA, F test

\begin{tabular}{lcc}
\hline $\mathrm{F}$ & Error & $\mathrm{P}$ \\
\hline 57.08 & 34305765011 & $<0001$ \\
\hline
\end{tabular}

Critical value of $\mathrm{F}\left(\mathrm{v}_{1}=2, \mathrm{v}_{2}=27\right)$ at $5 \%$ level of significance $=9.29263$

\subsubsection{F-test}

Table 8 as the calculated value of F-ratio (57.08) is more than the critical value of $\mathrm{F}$ at $5 \%$ level of significance, hence the null hypothesis is rejected and therefore it is concluded that return on investment trend In Royal Jordanian Airlines differs significantly.

\section{Recommendation}

\subsection{Recommendation for Managers}

A more careful attention should be paid by managers to IT investments to enable the positive impact of IT. A clear strategic plan and information technology plan is needed, as alignment between strategic objectives and IT is a major reason behind IT investments success.

Investments in IT should be accompanied by appropriate organizational change to increase the likelihood of a positive payoff. Information technology benefits intensify in those cases where IT investments are accompanied by corresponding changes in organizational characteristics.

The financial measures of performance are well adequate to monitor returns on IT. This is important as IT specialists always require special measures for IT performance, the current results show that IT do affect the aggregate financial performance measures. Which make them suitable for IT investments assessments.

\subsection{Recommendation for Further Research}

In light of the findings of negative relationships: impact of IT on profitability on airlines' A case study of Royal Jordanian Airlines' in this study, a call is made to try new methods in studying this important relationship. The findings of this study contribute to the debate of whether IT investment adds value in any way to quantifiable performance outcomes. The unexpected negative relations found have emphasized the need to incorporate the contextual features of qualitative studies so that it could be discovered what organizational factors are important in facilitating positive relationship between IT and profitability. 
Future research should go beyond estimating the average effects of IT and focus on identifying best practices, either in terms of specific characteristics or as overall strategies of specific firms.

Finally, from this analysis, it can be concluded that in some ratios, Royal Jordanian Airlines showed good results .Looking and considering these facts, Royal Jordanian Airlines can improve effectively its financial performance and long term and short-term solvency in future.

\section{References}

Albert H. S., \& Varun G. (1995). The Industry-Level Impact of Information Technology: An Empirical Analysis $\begin{array}{lllll}\text { of Three Industries. Decision 337-368. } & \text { Sciences, }\end{array}$ http://dx.doi.org/10.1111/j.1540-5915.1995.tb01432.x

Batra G. S., \& Dangwal R. C. (2001). Commerce and Business Research, New Horizons. New Delhi: Deep \& Deep Publications Pvt. Ltd.

Batty, S. (1982). Management Accountancy. Mac- Donald and Evans.

Bierman, Harold Jr. (2003). Financial and Management Accounting - An Introduction. New York: Mcmillan Company.

Blesucax Harold Jr. (2007). Measurement Accounting (P. 149). California: Dickenson Publishing Co.

Booth, M., \& Philip, G. (1997). Technology, competencies and competitiveness: the case for reconfigurable and flexible strategies. Journal of Business Research, 41, 29-40. http://dx.doi.org/10.1016/S0148-2963(97)00009-X

Brigham, E. F., \& R. E. (1999). Fundamentals of Financial Management (4th ed.). The Dryden Press.

Bright, M. G. (1978). Financial Management. New Delhi: Tata McGraw Hill Publishing Co. Ltd.

Chandra, Prasanna. (2007). Financial Management - Theory and Practice. New Delhi: Tata McGraw Hill Publishing Co.

Costales, S. B. (1977). The Guide to understanding Financial Statement. New York: McGraw Hill.

Das, Gupta, N. (1997). Financial Reporting in India. New Delhi: Sultan Chand and Sons.

Dauten, K. A. (1956). Business Finance. Englewood Cliffs: N.J. Prentice Hall Inc.

Dimitrios B. (1998). Strategic use information technologies in the tourism industry. Tourism management, 19(5), 409-421. http://dx.doi.org/10.1016/S0261-5177(98)00038-7

Dimitrios B. (2004). eAirlines: strategic and tactical use of ICTs in the airline industry. Information and management, 41(7), 805-825. http://dx.doi.org/10.1016/j.im.2003.08.015

Dussauge, P., Hart, S., \& Ramanantsoa B. (1994). Strategic Technology Management. European Management Journal, 22(1), 87-98.

J. G. M. Van Der Heijden. (1996). The changing value of travel agents in tourism networks: Towards a network design perspective. In Stefan Klein et al. (eds.), Information and communication technologies in tourism (PP. 151-159). New York: Springer-Verlag.

Laudon, K. C., \& Laudon, J. P. (1998). Management Information Systems: New Approaches to Organization and Technology (5th ed.). London: Prentice Hall International Inc. 